\title{
The Russian social engineering attack on the President of the Republic of Poland as a manifestation of modern soft power
}

\section{Original article}

Accepted: September 2020

Published: November 2020

\section{Peer review:}

Double blind

\section{Keywords:}

soft power, security, defence, information warfare, social engineering

This work is licensed under the Creative Commons AttributionNonCommercial-NoDerivatives 4.0 License

\author{
Jacek Bil ${ }^{1}$ \\ ORCID: 0000-0002-9586-528X \\ Military University of Technology in Warsaw, \\ gen. Sylwestra Kaliskiego 2, 01-476 Warszawa
}

\begin{abstract}
The tools of exerting soft power constitute an effective instrument of information warfare conducted by intelligence services of many countries. The Russian disinformation machine, as well as other methods it uses in information warfare, seem to be effective in destabilising other countries' security and defence systems. Purpose: The purpose of this article is to bring to the attention the social engineering attack on the President of the Republic of Poland that took place either immediately after or at the final stage of the election in Poland. Method: The article was designed using the problem-based method with elements of comparative analysis. The research part was carried out using the method of critical analysis of academic literature on the topic of using soft power for achieving political goals. Results: The article presents an analysis of a recent attack by Russian pranksters on the President of Poland. It has been shown that this incident should be viewed as a dangerous manifestation of the information game played by Russia. Information about the attack was provided by the Polish Ministry of Foreign Affairs. The analysis of the content of the President's conversation with the pranksters posted on Russian portals prove the existence of a real information warfare against the security of the Polish state, aimed at destabilisation of the defence system of our country. The call made by the Russian pranksters fits into the Russian strategy of exerting soft power. Conclusions: The action taken by the Russian pranksters can certainly be regarded as an example of information warfare aimed at weakening the state security system and its defence capabilities. The provocative conversation between the Russian pranksters and the President of Poland, Andrzej Duda, was criticised by mass media, which accused the Ministry of Foreign Affairs and the President's Chancellery of neglect in terms of ensuring the safety of the Polish head of state. Such accusations against those responsible for the president's safety seem to be justified.
\end{abstract}

${ }^{1}$ Prof. Jacek Bil, Ph.D. is a professor and researcher at the Institute of Security and Defence at the Department of Security, Logistics and Management of the Military University of Technology in Warsaw. The author's scientific interests include mainly issues related to the economic security of the state and the state's foreign policy in view of aspects of international security. 


\section{Introduction to the problem}

Vladimir Kuznetsov and Alexei Stolyarov, two Russian pranksters succeed in bypassing and breaking the security system for telephone calls of the President of the Republic of Poland, hold an 11-minute long conversation with Andrzej Duda, head of the Polish Armed Forces, at the end of the 2020 presidential election in Poland ${ }^{2}$. Disregarding technical aspects that allowed such an interview to be conducted by unauthorized persons, as well as shortcomings of the president's security system, the author chose to analyse the content of the interview in terms of the most important aspects of the conducted information warfare. Disinformation operations that are carried out by Russia in the Baltic states as well as in former member states of the Warsaw Pact represent a repeatable pattern alluding to the "Great Patriotic War" and the recognition of the heroism of the Red Army soldiers. During the conversation in question, the interlocutors ask the President about the monuments commemorating Red Army heroes in Poland. A well-known example used by Russians for their disinformation campaign in the Baltic states is the issue of the so-called "Bronze Soldier". Relocation of the Monument to the Liberators of Tallinn (as it was originally named) from the centre of the city to the military cemetery sparked off riots and caused destabilisation of the security system of Estonia, as well as a serious diplomatic crisis between Estonia and Russia. Russia very often plays on the historical aspect, invoking the victims of World War II, in order to achieve its goals.

\section{Conversation between the Youtubers and President Andrzej Duda}

The eleven-minute long conversation between Vladimir Kuznetsov, posing as UN Secretary General António Guterres, and the President of Poland, Andrzej Duda, was uploaded on the Vovan222prank YouTube channel. It was conducted in English. Using the technique of social engineering manipulation, the Russians start the conversation with congratulations on winning the presidential election, which at the later stage of the conversation facilitates asking specific questions. In addition to the issues related to the COVID-19 pandemic, the two Russians, being aware of the President's relationship with Donald Tusk, provoke him to voice his opinion about the politician as well as issues related to homosexuality. However, the above-mentioned questions serve only as a manoeuvre to move to the actual point, which concerns the diplomatic relations between Poland and Russia as

\footnotetext{
${ }^{2}$ I. Kacprzak, Rosyjski internauta podszył się pod sekretarza generalnego ONZ, by porozmawiać z prezydentem Andrzejem Dudą. Eksperci: to był atak socjotechniczny, Polityka, https://www.rp.pl/Polityka/200719544-Polskiprezydent-wkrecony-przez-youtubera.html, accessed on [26.07.2020].
} 
well as defence issues of $\mathrm{NATO}^{3}$. In order to achieve the main goal of the prank - tricking the President into making a discreditable statement - Kuznetsov says to Duda (the dialogue is quoted verbatim): "By the way, you are still fighting. I admire your victories over some monuments in Poland. This is a very difficult battle", to which the President replies: "Yes, it was very difficult, that's true”. The analysis of the dialogue reveals that Kuznetsov, wishing to direct the conversation to the controversial topic, adds: "'I mean, you had a lot of fight with monuments of the Red Army in Poland", to which the president replies: "No, that is not true. We have had a few cases. But only a few. This is not a very intensive problem". In order to provoke the President into showing an anti-Russian attitude, the Russian prankster argues: "I heard that you have a struggle with Mr Putin", to which Andrzej Duda replies: "We have a discussion about history with Mr Putin. Because he accused us that we started the Second World War". As this was not the declaration he wanted from the President, Kuznetsov continuing the topic of the "patriotic war" - asks Andrzej Duda: "But you should know that Russia also took a big part in the victory". Though admitting the sacrifice of Russian soldiers During World War II, the Presidents points out, however, that: "The problem was that they also occupied our country after the Second World War”. In spite of the President's statements, Kuznetsov reiterates that Poland is fighting with monuments ("It's a good way to fight against monuments"), which indicates that this element of the conversation is particularly important for the Russians. Further in the discussion, which moves on to the topic of the Russian occupation and historical narratives, the issue of Lviv and other territories that were part of Poland before World War II is raised. This should be considered as another provocation, this time aimed at destabilising the political relations with Ukraine. Continuing to probe into the Polish-Ukrainian relations, Kuznetsov asks Andrzej Duda about the president of Ukraine and whether, according to Duda, he is a "good man". Maintaining the narrative of Eurasianism and the anti-NATO attitude, the Russian prankster - in a disguised manner - asks Duda about Poland's cooperation with NATO and the relationship with Donald Trump. ${ }^{5}$

The style of the conversation between the Russian and the Polish President is far from the standards adopted in the diplomatic discourse and cannot be treated as an official position

\footnotetext{
${ }^{3}$ Gazeta.pl, Andrzej Duda wkręcony przez youtuberów, serwis YouTube, https://www.youtube.com/watch?v=n6 ydnzhMSUU, accessed on [23.07.2020].

4 Translator's note: Most likely what was meant here was "reason"

${ }^{5}$ Wprost.pl, Tusk „go nie lubi”, wcale nie dyskryminuje LGBT i nie chce odzyskać Lwowa. Zapis rozmowy Dudy z pranksterami, https://www.wprost.pl/polityka/10344458/tusk-go-nie-lubi-wcale-nie-dyskryminuje-lgbt-inie-chce-odzyskac-lwowa-zapis-rozmowy-dudy-z-pranksterami.html, accessed on [23/07.2020].
} 
or point of view of the Russian foreign policy makers. Nevertheless, the timing of the interview and the topics raised lead to the conclusion that humour was not the only objective that guided the interviewer.

\section{Core elements of the concept of soft power}

In 1990, the term "soft power" was popularised in a book by Joseph Nye "Bound To Lead: The Changing Nature Of American Power". The concept presented by Nye met with considerable criticism, which concerned the lack of clear definition of the introduced concept. Many recipients did not understand the difference between soft and hard power. The main criticism was that soft power cannot be defined in separate terms, as it has the same intrinsic purpose as hard power. In addition, soft power was compared to the concept of hegemony proposed by an Italian politician - Antonio Gramsci. Defending his idea, Nye refuted the criticism with the claim that the critics had simply failed to understand the concept, and pointed out that the United States, in addition to its economic and military power, also wielded soft power, which should be considered as the third dimension of power. In his theory, Joseph Nye defines soft power as:

$\checkmark$ the ability to exert pressure on others in order to obtain the desired results;

$\checkmark$ the ability to shape the preferences of others;

$\checkmark$ unlike hard power, which uses the carrot and stick method, money and threat, soft power indirectly manipulates others into acting as one wants;

$\checkmark$ soft power is not limited to the power of persuasion, it also applies to the ability to attract others;

$\checkmark$ it has a persuasive impact and can offer convincing arguments;

$\checkmark$ both soft and hard power are used to influence the behaviour and attitude of others; the difference lies in the use of tools and methods. While hard power makes use of such aspects as physical power and threat, soft power appeals to such values as, for example, culture and education; it also includes the ability to manipulate election manifestoes;

$\checkmark$ soft power is also the ability to achieve the desired results through persuasion or attractiveness;

soft power arises from the attractiveness of one's own politics, political ideas and culture (Taskin, 2019, 5-9).

Nye points out that soft power is based on three basic resources: culture, political values, and foreign policy. Some of the indicated resources may be attractive while others may not. Therefore, it is necessary to make unattractive resources look like a desirable 
product for a potential recipient. Craig Hayden, in his book "The Rhetoric of Soft Power; Public Diplomacy in Global Contexts", argues that hard power resources are related to leadership skills, while soft power resources are based on the process of co-option. Culture, according to Hayden, is one of the greatest resources of soft power. In the book "The Future of Power" Nye suggests two soft power models: direct and indirect. Under the direct model, it is the government of a given country (entity) that makes active efforts to achieve the intended goal, In turn, under the indirect model, the goal is achieved by using the population of the country attacked (Taskin, 2019, 10-17).

Tom Patterson, discussing the instruments of soft power, observes that there has been a significant increase in the potential of soft news in the media, defined by the author as news that is typically more sensational, more personality-centred, less time-bound, more practical, and more incident-based than other news. According to Matt Bauman, the majority of people would not watch the news if the content was presented in a conventional way. In turn, the structure of soft news allows it to reach a wider audience, the major part of which focuses on the more fun, shocking or outrageous aspects of politics. The "soft" way of disseminating information offers people a more useful alternative in the form of infotainment, combining entertainment with information. Bauman also emphasises the criterion of the amount of attention paid to wars and political crises. An essential factor required for attracting people's interest in the content of the news as well as shaping an informed opinion is informative value of the news. Assuming that soft news not only has the potential to reach people who were previously not interested in news, but also helps to broaden their knowledge on political issues, the important role that it plays in a democratic system should be highlighted. On the other hand, if soft news diverts people's attention to the entertaining side of political issues, offering no educational value, then soft-power communication becomes a potent tool for manipulation (Prior, 2003, 149-150). Compared to hard power, soft power measures consist in forcing others into a specific action by generating in the recipient's mind a conviction that the given action is attractive or desirable. The tool and measures of soft power appeal to the values that make the object of attack take the side of the aggressor as favourable. The instruments of soft power may have a cultural nature, if the culture of a given country is similar to that of the aggressor's country. This is well illustrated by the results of the report "Russia's influence and presence in Estonia". On the basis of the collected data, the report presents a list of the countries under the influence of Russian soft power, with Poland ranking 
first $(68 \%)^{6}$, followed by Estonia (58\%), Romania (56\%), Ukraine (53\%), Georgia (48\%) and Lithuania (45\%). Others countries vulnerable, albeit to a lesser extent, to the aggressive impact of the Russian soft power include Bulgaria, Slovakia, the Czech Republic, Hungary and Moldova. The target of soft power are both the elites as well as ordinary people (Nielsen \& Paabo, 2015, 128-129).

\section{Narratives in the Russian media regarding the pranksters' conversation with President Andrzej Duda}

On July 15 2020, in the article "Rossiyskiye prankery prokommentirovali razgovor s prezidentom Pol'shi Korotkaya ssylka" published on the russian.rt website, Vladimir Kuznetsov (aka Vovan) commented that he felt excitement and attempted to address the Polish President in a respectful manner, carefully choosing his words. In his opinion, Andrzej Duda was convinced that he was talking to the UN Secretary General António Guterres. Kuznetsov admitted that Poland had launched an investigation regarding the telephone conversation, but was at the same time wondering how it was possible that random people had been able to reach the head of state. The pranksters' overall perception of the conversation with Andrzej Duda was positive ${ }^{7}$.

Quite a different rhetoric is presented in the article "Golos drozhal»: Vovan i Leksus rasskazali podrobnosti rozygrysha prezidenta Pol'shi” that appeared on the VM.RU website on July 15. Vladimir Kuznetsov and Alexei Stolyarov (aka Lexus) commented that the President of Poland was using bad English throughout the conversation, stuttered every second word and there was a note of trembling in his voice. From these three criticised aspects, what surprised Kuznetsov most was the poor level of the interviewee's English. The pranksters commented that they were under the impression that someone who had been a Member of the European Parliament before should have mastered English, but it turned out this was not the case. Kuznetsov and Stolyarov, citing comments made by Polish Internet users, observed that even Poles and Americans themselves often make fun of Andrzej Duda's English pronunciation. Kuznetsov also remarks that the call, which the President believed was from the UN secretary general, really shocked Duda and it was evident in his trembling voice. At the same time, the pranksters remarked that the most sensitive topics for the President of Poland seemed to be the issues concerning the relations of Poland with the European Union and the country's territorial claims to Ukraine. They indicated that when asked about the most

\footnotetext{
${ }^{6}$ Values on a scale from 0 to $100 \%$.
} 
likely direction of development of the relations with the European Union, Andrzej Duda only "let out a deep sigh and said nothing more". The Russians claim that such a reaction was caused by the fact that the recent presidential election in Poland also involved choosing between the pro-US and the pro-EU option. Andrzej Duda's re-election meant the victory of the pro-American approach, not the pro-European one, represented by Rafał Trzaskowski Duda's opponent in the election. Regarding Ukraine-related issues, the bloggers claimed that Duda's statements about the western Ukrainian lands that were once part of Poland and the possibility of their return to our country were insincere. According to Kuznetsov, had Andrzej Duda not been convinced he was talking to the Secretary General of the United Nations, his stance regarding those issues would be completely different. Aleksei Stolyarov observed that if a conversation like that was conducted with Andrzej Duda a week earlier, it could significantly affect the outcome of the election and even lead to Duda's defeat. Stolyarov also informed that he was receiving messages from many Polish people, who assure him that if Duda showed in the presidential campaign a negative stance towards the re-incorporation of previously Polish lands (which the authors of the messages still consider as Polish) now belonging to Ukraine, he would lose to Trzaskowski. Continuing the topic of political relations (this time, in turn, at the personal level, the pranksters quoted Andrzej Duda, who, without going into details, admitted that the former Prime Minister of the Republic of Poland, Donald Tusk, did not like him. Stolyarov also mentioned Tusk's tweet posted in a response to the President's words 8 .

The article "Prezident Pol'shi prokommentiroval zvonok rossiyskikh prankerov", posted on the RT website, referred to the reaction of the Polish president regarding the prank conversation. quoting his tweet, in which he said that during the conversation he realised something was wrong, as, according to Duda, the Secretary General did not pronounce the word "żubrówka" so well ${ }^{10}$. Russian media report that similar conversations were conducted by Stolyarov and Kuznetsov in May 2020 with the mayor of Prague, after the removal of Ivan Konev's monument, as well as in 2014 with Alexander Lukashenko, whom the pranksters -

\footnotetext{
7 RT, Rossiyskiye prankery prokommentirovali razgovor s prezidentom Pol'shi, /764673-polsha-rossiyakommentarii, [accessed on; 30.07.2020].

8 P. Golos drozhal»: Vovan i Leksus rasskazali podrobnosti rozygrysha prezidenta Pol'shi”, https://vm.ru/policy/815025-prankery-vovan-i-leksus-podelilis-vpechatleniyam-posle-rozygrysha-prezidentapolshi, [accessed on:30.07.2020].

${ }^{9}$ A Polish brand of vodka

${ }^{10}$ RT, ,Prezident Pol'shi prokommentiroval zvonok rossiyskikh prankerov” https://russian.rt.com/world/news/764614-duda-zvonok-prankery, [accessed on:30.07.2020].
} 
posing as the son of former Ukrainian president Viktor Yanukovich - asked for asylum in Belarus ${ }^{11}$.

Speaking to the media ("Leksus rasskazal, kto pomog yemu ustroit' razgovor $\mathrm{s}$ prezidentom Pol'shi" published on gazeta.ru), Aleksei Stolyarov indicated that senior officials of the Polish Ministry of Foreign Affairs had helped to stage the conversation with Andrzej Duda (one of the officials apparently wished them good luck), and that the Polish UN ambassadors dismissed as a result of the prank call made by unauthorised persons has nothing to do with it ${ }^{12}$.

On Gazeta.ru, Vladimir Kuznetsov referred to the statement made by the now former Minister of Foreign Affairs, Jacek Czaputowicz, in which he indicated that the conversation between the President of the Republic of Poland Andrzej Duda and the pranksters posing as the UN Secretary General António Guterres was an element of Russian disinformation campaign. Kuznetsov categorically denied this allegation. He explained that the conversation with Andrzej Duda uploaded on the Vovan222prank YouTube channel was by no means controversial and nothing was edited or removed from it. He dismissed the accusations made by Czaputowicz as if the pranksters had been acting in order to damage the relations between Poland and Ukraine as unfounded. According to the Russian, Ukraine was not the only subject discussed during the conversation. The pranksters also brought up the issues related to Duda' opponent, the LGBT ideology and the presidential election. In addition, he observed that actually Andrzej Duda said nothing that could meet with critical reception in Ukraine. In the Youtuber's opinion everything was ethical and politically correct ${ }^{13}$.

Interfax (an international news agency in Russia) informed that the Ministry of Foreign Affairs of the Republic of Poland called on the Russian authorities to take action against Vladimir Kuznetsov, who was accused of spreading disinformation during the staged conversation with President Andrzej Duda. The Polish Ministry of Foreign Affairs argued that its purpose might have been be to sow discord between Poland and Ukraine. According to

11 BOTTAK, Pol'skiy prezident podtverdil, chto yego razygrali rossiyskiye prankery, https://vottak.tv/novosti/polskij-prezident-podtverdil-chto-ego-razygrali-rossijskie-prankery/, [accessed on:30.07.2020].

12 Gazeta.ru, Leksus rasskazal, kto pomog yemu ustroit' razgovor $\mathrm{s}$ prezidentom Pol'shi, https://www.gazeta.ru/politics/news/2020/07/17/n_14684317.shtml, [dostep;30.07.2020].

13 Gazeta.ru, Pranker Vovan prokommentiroval reaktsiyu MID Pol'shi na zvonok Dude, https://www.gazeta.ru/politics/news/2020/07/16/n_14677831.shtml, [accessed on;30.07.2020]. 
Jacek Czaputowicz, the questions asked by the interviewers prove that the prank call was actually a disguised disinformation operation ${ }^{14}$.

\section{Conclusions}

The provocative conversation between the Russian pranksters and the President of Poland, Andrzej Duda, was criticised by mass media, which accused the Ministry of Foreign Affairs and the President's Chancellery of neglect in terms of ensuring the safety of the Polish head of state. Such accusations against those responsible for the president's safety is by all means justified and a similar incident should not be allowed to happen again, as it discredits the state's security system. A thorough analysis of the incident indicated it was a dangerous manifestation of an information game played by Russia. Information about the attack was provided by the Polish Ministry of Foreign Affairs. The analysis of the content of the President's conversation with the pranksters posted on Russian portals prove the existence of a real information warfare against the security of the Polish state, aimed at destabilisation of the defence system of our country. The call made by the Russian pranksters fits into the Russian strategy of exerting soft power. The typical Russian narrative used against other countries, addressing such issues as monuments to Soviet soldiers or the heroism of the Red Army, was also present in the conversation with the President of Poland. Accusations of disregard of Russian sacrifice during World War II are still used as fuel for Russian politicians to win support from the Russian society, both in order to achieve its foreign policy objectives as well as internal goals. The analysis of Vladimir Kuznetsov's statements in Gazeta.ru, in which he denied conducting disinformation operations, confirms that the information game was not intended to undermine the credibility of the President of the Republic of Poland or ridicule any shortcomings in his communication skills, but its aim was primarily to:

$\checkmark$ demonstrate the potential to manipulate elections (in this case presidential elections),

$\checkmark$ destabilise the relations between Poland and Ukraine,

$\checkmark$ destabilise in an indirect way the defence system based on the alliance with the USA and the relations with European countries.

Alexei Stolyarov's statement regarding the timing of the interview and its potential impact on the election results is a clear declaration of the possibility of interference in presidential elections in Poland. It should be stressed that the date of the interview was not random, and the congratulations extended while the result of the presidential election in

14 Gazeta.ru, V MID Pol'shi nazvali aktom dezinformatsii RF rozygrysh Dudy prankerom, https://www.gazeta.ru/politics/news/2020/07/16/n_14677261.shtml, [accessed on;30.07.2020]. 
Poland was not final yet merely served as a sociological manipulation. After Russia's influence on the results of the presidential election in the United States was made known to the public, the attack on the Polish president should be interpreted as a projection of power by Russia in the information warfare related to the election process. Stolyarov's statement about the expectations of Polish people regarding the re-incorporation of the previously Polish parts of Ukraine was an element of the information warfare aimed at inciting anti-Polish attitudes in Ukraine. This kind of soft influence is targeted at nationalist groups both on the Polish and Ukrainian side. The issues of national minorities or territorial claims are frequently raised by Russians as part of their disinformation campaign. During the analysed conversation, the President of Poland was provoked to make anti-Russian and anti-Ukrainian statements. The topic of Ukraine was not chosen randomly, as it is related to building Poland's defence system and the eastern flank of NATO. The issue of Ukraine in the context of the global security system remains in the interest of both Russia and the United States. The analysis of the statements made by the pranksters also shows that the conducted disinformation operations are aimed at materialising the concept of Eurasia propagated by Russia. In contrast to Rafał Trzaskowski, whose concept of security is clearly pro-European, Andrzej Duda is commonly thought to represent the American philosophy of defence security. Undoubtedly, the separation of Poland from the structures of the European Union and the promotion of national initiatives, negating EU assumptions is desirable from the point of view of the Russian foreign policy. To conclude, it should be assumed that the aim of the sociological attack on the President of Poland conducted by Vladimir Kuznetsov and Alexei Stolyarov - two Russian pranksters, was much more sinister than to simply ridicule the shortcomings of the Polish President's telephone line security system. 


\section{References}

1. Kacprzak I. (2020) Rosyjski internauta podszyt się pod sekretarza generalnego ONZ, by porozmawiać z prezydentem Andrzejem Duda. Eksperci: to byt atak socjotechniczny, Polityka. Available at: https://www.rp.pl/Polityka/200719544-Polski-prezydent-wkreconyprzez-youtubera.html.

2. Nielsen, K., \& Paabo, H. (2015) 'How Russian Soft Power Fails in Estonia: Or, Why the Russophone Minorities Remain Quiescent', Journal on Baltic Security, 1(2), 125-157. doi:10.1515/jobs-2016-0023.

3. Prior, M. (2003) 'Any Good News in Soft News? The Impact of Soft News Preference on Political Knowledge', Political Communication, 20(2), 149-171. doi:10.1080/10584600390211172.

4. Taşkın I. (2019) The Impact of US Soft Power on The Restoration of Estonian Independence. MA Thesis. Tallinn University School of Humanities, Tallinn.

5. Wprost.pl (2020) Tusk ,,go nie lubi”, wcale nie dyskryminuje LGBT i nie chce odzyskać Lwowa. Zapis rozmowy Dudy $z$ pranksterami. Available at: https://www.wprost.pl/polityka/10344458/tusk-go-nie-lubi-wcale-nie-dyskryminuje-lgbt-inie-chce-odzyskac-lwowa-zapis-rozmowy-dudy-z-pranksterami.html.

6. Zalyan P. (2020) ,,Golos drozhal»: Vovan i Leksus rasskazali podrobnosti rozygrysha prezidenta Pol'shi”. Available at: https://vm.ru/policy/815025-prankery-vovan-i-leksuspodelilis-vpechatleniyam-posle-rozygrysha-prezidenta-polshi. 